\title{
Healing to Kill the True Internal Enemy
}

We all thought: "We must work ourselves to the bone; saving one more wounded soldier is like killing one more devil [i.e., Japanese soldier]!"

- YAO AIHUA, RECALLING HER WORK AS A VOLUNTEER MILITARY NURSE DURING THE WAR

Though everyone assumed that war with Japan would eventually come, the actual moment caught the Nationalist government off guard and very nearly destroyed it. What came to be called the Marco Polo Bridge Incident (Lugouqiao shibian) took place just outside Beijing on July 7, 1937. Both sides' stubborn refusal to cooperate turned what might have been an isolated affair in the regional North China war that had begun soon after the Japanese colonized northeastern China (Manchukuo) in September 1931 into a full-blown war that engulfed the country and, a few years later, the entire Pacific. ${ }^{1}$ During the first several months of fighting, Japanese soldiers tore through Chinese cities and villages, advancing like an uncontrollable forest fire and wreaking havoc on civilians and soldiers alike. Their rapid conquest of a vast territory, including the old imperial capital, Beiping (Beijing), and the actual capital, Nanjing, caused a health crisis that prompted the Nationalist state finally, belatedly, to fund and administer military medicine. ${ }^{2}$ Though it grew as quickly as possible during the war, the underfunded and understaffed military medicine system could never catch up to the burning need, and young students like Yao Aihua, quoted in this chapter's epigraph, rushed in to fill the gap. ${ }^{3}$

Yao characterized her medical work in terms that simultaneously underscored its urgency and its role in supporting the Chinese military's aim to kill the enemy. She and her fellow nurses therefore supported the Nationalist state's ability to kill, by serving as the caring and benevolent face of a state that extended its reach into hearts and homes to save lives while simultaneously risking the lives of millions of men on the battlefields. Achille Mbembe argues that the political sovereignty of the modern state lies not only in its biopolitics-the structures it creates to 
affirm and protect life, such as schools and hospitals—but also in its necropolitics: its ability to determine who shall live and who must die. ${ }^{4}$ The Nationalist state's killing machine-its organized military-placed at great risk not only the lives of Japanese enemy soldiers, but also the lives of its own soldiers, and women who worked in military medicine quite deliberately and consciously did the same. As Yao Aihua's words suggest, military nurses understood this direct connection between the work of healing and the burden of killing and in fact celebrated their ability to contribute to the war effort by nurturing the bodies of their own soldiers so that they could return to attacking the bodies of enemy soldiers.

Nurses could overlook their role in risking the lives of their own soldiers because they spent so much time and energy killing the soldiers' greatest enemy: disease microbes. Whereas in other belligerent nations battle had become the troops' most lethal threat (unlike during World War I), in China, with the exception of the first few months of the war, infectious disease and poor hygiene and nutrition still proved far more deadly than enemy soldiers. ${ }^{5}$ Cholera, bacillary and amoebic dysenteries, typhoid, typhus, scabies, malaria, tuberculosis, tetanus, and relapsing fever all ravaged Chinese troops in an era when most of these diseases claimed easy victims. Among civilians, the burden of disease fell heaviest on the poor, and infantrymen-who often came from poor families and once in the army received insufficient food, clothing, and medical care-faced the greatest danger of all. Women who offered medical care formed a bulwark against these myriad threats and embodied the soldiers' hope of survival, even as they eagerly sent the soldiers back to the battlefield.

These women performed a crucial service for their country as well. Despite the rush of volunteers, staffing remained an intractable problem because China suffered a critical shortage of medical personnel. A 1937 survey of registered scientific-medicine professionals counted only 8,900 physicians, 2,740 pharmacists and druggists, 3,700 midwives, and 575 nurses nationwide. ${ }^{6}$ In order to address this pressing problem, Major General Zhou Meiyu translated her training program for rural public health nurses into the military. Working with a man who had close ties to overseas funders, Dr. Lim Kho Seng (Robert Lim), and for a state that desperately needed her services, Zhou trained a large cadre of nurses more successfully in wartime than she could have done in peacetime since even as the Nationalist state's capacity shrank, the generosity of foreign donors grew. ${ }^{7}$ Under the leadership of Lim and Zhou, the Chinese Red Cross Medical Relief Corps (Zhongguo hongshizihui jiuhu zongdui) (MRC) and the Emergency Medical Service Training School (Zhanshi weisheng renyuan xunliansuo) (EMSTS) trained frontline medics, stretcher bearers, and nurses as rapidly as possible. Working independently of but in cooperation with the government-run Army Medical Administration (AMA), the MRC and EMSTS formed the structure of a new military medical system. ${ }^{8}$ 
Ironically, the greatest peril to this system designed to protect soldiers' lives came from the Nationalist state itself. Many powerful state officials failed to recognize the terrible threat of disease and believed other entities more dangerous. According to Generalissimo Chiang Kai-shek, Communist "bandits" were the country's true "internal enemy" and deserved only death and suffering. Therefore, he and his allies grew suspicious of medical workers who treated all patients equally. They failed to understand the foundational role that emotional labor played in the provision of healthcare and decided that only Communists could feel genuine care for soldiers of the Communist armies. This emotional blind spot greatly strained China's military medicine system when Nationalist party rightists pushed Dr. Lim out of his leadership roles in the MRC and EMSTS, thereby threatening their smooth operation.

\section{WHOSE “DISEASE OF THE HEART”? POLITICAL MYOPIA AND THE FATE OF THE NATION}

The trouble began with defining the enemy. Three months before the war began Minister of Health Dr. Liu Ruiheng declared,

China is on the eve of launching a great organized advance towards the elimination of preventable diseases. There are hordes of enemies which are destroying the national health and vigor, and until very recently no organized attempts have been made to retaliate. ${ }^{9}$

Depicting diseases as "hordes of enemies ... destroying the national health and vigor," and fighting contagious disease as the foundational task of protecting national sovereignty, Minister Liu (and other health officials) attempted to coax the Nationalist government into committing precious resources to health programs. Although civilian and military healthcare gained substantial ground during the war, in many respects Minister Liu was shouting into the dark. When in 1941 Time magazine correspondent Theodore H. White interviewed General Chiang Kai-shek, the head of the Nationalist government famously stated, "[Y]ou think it is important that I have kept the Japanese from expanding. ... I tell you it is more important that I have kept the Communists from spreading. The Japanese are a disease of the skin; the Communists are a disease of the heart." ${ }^{{ }_{10}}$ While Chiang described the Communists as the country's true internal enemy, piercing the heart of the body politic, health officials more accurately described disease microbes-the internal enemy that penetrated a body's cells-as "hordes of enemies" that rendered soldiers unable to fight and civilians unable to rebuild the nation.

These definitions mattered. Because Generalissimo Chiang and other rightwing Nationalists treated Communists as sworn enemies, medical workers who 
treated them as fellow Chinese in need of care angered political leaders and faced personal danger. Right-wing Nationalists assumed that people who accepted the many privations of working in wartime healthcare must be devotees of Communist doctrine, for they could not conceive of another source of motivation. They understood only one of the two modes in which patriotism operates, for

[p]atriotism is Janus-faced. It faces outward, calling the self, at times, to duties toward others, to the need to sacrifice for a common good. And yet, just as clearly, it also faces inward, inviting those who consider themselves "good" or "true" Americans [Chinese] to distinguish themselves from outsiders and subversives, and then excluding those outsiders. ${ }^{11}$

On the one hand, patriotism promotes philanthropic behavior toward people one considers part of one's community. On the other hand, it can promote social ostracism and mistreatment of those who are considered not part of this community. Precisely because Nationalist party rightists considered Communists and their political sympathizers a "disease of the heart," or outsiders inside the national community, they insisted that Communists receive no medical care when wounded. In other words, rightist ideologues had their own "disease of the heart" - the failure to understand that someone might wish to help all wounded compatriots out of simple patriotism, professional identity, or humanitarian impulse, rather than political alliance. This failure of imagination led them to decide that prominent military health leaders who followed the nonpartisan protocol of the International Committee of the Red Cross must be Communist, and therefore must be eliminated.

Dr. Lim Kho Seng (1897-1969), an overseas Chinese from Singapore, was the first to face this allegation. Dr. Lim exhibited the philanthropic form of patriotism from the beginning. On sabbatical in Europe when the war broke out, he gave up both his sabbatical leave and his appointment at the Peking Union Medical College (PUMC) to serve his ancestral homeland. ${ }^{12}$ Once in China he established and ran the Chinese Red Cross Medical Relief Corps (MRC), which by November 1941 had trained nearly three hundred thousand medical personnel organized into 175 mobile medical teams. ${ }^{13}$ Lim also established the Emergency Medical Service Training School (EMSTS), which by the spring of 1941 had trained nearly five thousand doctors, nurses, midwives, hygiene technicians, sanitation inspectors, and orderlies for both military and civilian services. Fully committed to serving anyone in need, Dr. Lim insisted that MRC units offer treatment not only to soldiers, but also to local farmers on the front lines. ${ }^{14} \mathrm{He}$ also assigned some of the MRC units to serve the Communist Eighth Route and New Fourth Armies, and he sent a division of the MRC to the Communist headquarters in Yan'an to treat people who had been wounded in guerrilla fighting in North China. ${ }^{15}$ After facing pressure from multiple sides that left him in a constant state of fear, Lim resigned 
from the MRC in September 1942, and the organization entered a serious decline that lasted until December 1944, putting the country's military medical system at an extreme disadvantage precisely when the Imperial Japanese Army (IJA) launched Operation Ichigo (April-December 1944), the largest land offensive of the conflict, during which Japan nearly conquered China. Lim was also forced to abandon his position as head of the EMSTS in August 1943. Lim's colleagues kept the EMSTS in operation, however, and by late 1943 had trained over seven thousand medical officers and assistants, and over sixteen thousand by the war's end. Nonetheless, leading doctors in the EMSTS described Lim's departure as "an irreparable loss." ${ }^{16}$

This all occurred well after the New Fourth Army Incident of January 1941 spelled the death of the Second United Front and heightened mutual distrust between the two parties. In this same period, Chiang Kai-shek also disbanded Yao Aihua's medical service team on the suspicion that its members had Communist leanings since Mao Zedong and Zhou Enlai had publicly praised their service to wounded soldiers in the famous battle of Taierzhuang. (Yao's team soon regrouped.). Yao also recalled being transferred out of the 77th Regiment Hospital after half a year when the hospital administrators noticed how friendly she was with the New Fourth Army soldiers. ${ }^{17}$ In a country with two fronts such friendships were politically suspect, but their interruption placed the nation at great peril.

Selfless service characterized not only Dr. Lim but the entire staff of both organizations he ran. To recruit personnel for the EMSTS, in October 1938 Dr. Lim visited Wuhan with Minister of Health Liu and delivered rousing speeches to educated refugees. In a short time the two men recruited over seven hundred doctors and nurses, with PUMC affiliates making up the majority. ${ }^{18}$ Lim and Liu's success reflected the strength of their professional networks revolving around the PUMC, the emotive power of the war as a motivator to action, and the singularity of the war as a historical moment when a high concentration of educated people with fewer career options than in peacetime committed themselves to serving their country. Remarkably, Drs. Lim and Liu recruited so many people even though they offered such little compensation; MRC and EMSTS staff received a pay so low as to render their service virtually voluntary. This mattered little. Yang Wenda (PUMC, class of 1937), who as superintendent of the Chinese Red Cross Hospital supervised the training of hundreds of army doctors, so desired to serve his country that he declared himself willing even if he received no pay whatsoever. He noted that he and his colleagues worked alongside actual volunteers who included not only Chinese from within China and throughout the diaspora, but also nonChinese from eleven countries around the world, including Romania, Poland, England, Germany, Spain, and India. ${ }^{19}$ The presence of an international coterie of volunteers strengthened the employees' conviction that they worked toward a higher purpose. 
Despite her distinction as one of the highest-ranked women in the National Revolutionary Army, Major General Zhou Meiyu also came under suspicion of being Communist and nearly lost her life when a Nationalist official sent someone to assassinate her. When the friend who had saved her told her of this plan, she merely scoffed and said, "That would be a waste of a gun. I'm not afraid!"20 The mere idea that a member of her own political party might assassinate Zhou, who dedicated herself to saving soldiers' lives, seems absurd now but made sense amid the political paranoia that gripped the Nationalist Party during the war. In her oral history interviews in the 1980 os Zhou felt compelled to explain: "At that time some people were very shortsighted and narrow minded; they always believed that if a person was doing something and asking nothing in return, they must be communist. This really was a big joke!"21

Though Zhou attempted to use laughter to dispel concern, this was not in fact a joke, or rather it was a big joke masterfully played on the Nationalists themselves. The emotional blind spot of radical Nationalists threatened the political stability of the country. Writing toward her own political goal (to promote the cause of cultivating certain emotions as the basis of liberal democracy), political philosopher Martha Nussbaum argues that "[c]eding the terrain of emotion-shaping to antiliberal [Communist] forces gives them a huge advantage in the people's hearts and risks making people think of liberal [Nationalist] values as tepid and boring." ${ }^{22}$ Given that Mao Zedong famously declared to the Politburo during the Civil War, "[T]he battle for China is a battle for the hearts and minds of the peasants," ${ }^{23}$ the significance of the rightist ideologues' myopia is clear. They forgot that "patriotic emotion can be a necessary prop for valuable projects involving sacrifice for others." ${ }^{24}$ They deliberately discharged nurses who befriended the soldiers to whom they provided medical care. This amnesia-or failure to understand in the first instance-ultimately cost them the country. During the Civil War, which bubbled beneath the surface of the War of Resistance and rolled into the open almost as soon as Japanese troops left, "the Communists proved far more effective than the Nationalists in mobilizing individuals and mass support by appealing to patriotism and anti-Japanese sentiment," and they won the war, and the country, in $1949 .{ }^{25}$ The Communists understood how to build a national community on sympathy.

Nationalist leaders' paranoia did not secure their goal of uncontested power, but its exact opposite. All the midnight arrests and back-alley executions of Communists and suspected Communists proved again and again that Nationalist Party ideologues valued their own ideals more than human lives. ${ }^{26}$ It also rendered the Nationalist Party ideologically empty, so the Communist Party could fully monopolize the spirit of service and personal sacrifice, even though in reality people across the political spectrum had this spirit, and both sides were simultaneously engaged in bloody conflict and suppression of "enemies." Extreme rightists relin- 
quished the narrative of wartime patriotism because they failed to understand that the affective domain of healthcare existed within a politics of inclusion, rather than a politics of exclusion. General Chiang did understand the importance of caring emotionally as well as physically for soldiers, as demonstrated in the speech he delivered to military medical officers soon after the war erupted. Chiang told them,

Our average soldier at the front, because he cannot rely on good military medicine and stretcher bearers, even as he fights bears the weight of worry over the fact that no one will be able to save him should he get wounded, and even should he be transported to the rear he still fears that he will not be healed, or even receive cruel and unfeeling [lengku wuqing] treatment in hospital. This decreases the soldier's courage in combat, and who can say how much it decreases our fighting strength? ${ }^{27}$

The key to Chiang's myopia lies in the first word, "our." He believed that care from "kindly doctors" (cixiang de yisheng) and "brave medics" should be limited to "our" people and denied to "theirs." ${ }^{8}$ His virulent anticommunism left him unable to fathom that people who treated everyone equitably did not necessarily do so out of a commitment to communism. Nationalist ideologues who followed Chiang's lead consistently isolated and mistreated members of their own party who accepted personal discomfort to serve those less fortunate, and who performed this service in a spirit of equity. ${ }^{29}$ Fortunately, Zhou Meiyu kept her calm and her life, and trained nurses to serve everyone who needed their care.

\section{MICROBES: THE TRUE INTERNAL ENEMY}

Chinese soldiers sorely needed people like Zhou Meiyu to accept personal sacrifices in order to help them, for their suffering knew no bounds. Soldiers faced hunger, exposure to extreme cold and extreme heat, and well-equipped enemies trained to treat them like animals. But their greatest enemies were invisible. After the first few months of blistering warfare far more Chinese soldiers died from the effects of pathogenic microbes than directly from wounds. Although the ratio of the total number of soldiers who succumbed to disease to the total number of wounded is fairly well matched-1.3 to 1.0 -disease proved far deadlier than battle wounds. Whereas 44,847 soldiers perished of wounds in hospital, 405,753 perished of disease in hospital, a ratio of more than 9 to $1 .^{30}$ Just as Dr. Liu Ruiheng claimed, pathogens were "destroying the national health and vigor." Over the course of the eight years of warfare the National Revolutionary Army lost over half of its total fighting force to disease, wounds, and desertion. ${ }^{31}$ This had devastating effects on units stationed throughout the country. For example, in a one-year period in which his nearly half a million troops saw no major battles, nine thousand of General Xue Yue's soldiers died from wounds and forty thousand of disease. ${ }^{32}$ 
Dreaded influenza-the same disease that sparked a global pandemic after World War I-earned pride of place on the list of lethal diseases, which also included tuberculosis, malaria, typhus, typhoid, and bacillary and amoebic dysenteries..$^{33}$

In 1945, a professor of agricultural biology estimated that fecal-borne diseases caused fully one-quarter of China's annual deaths. These diseases included some of the soldiers' main scourges-cholera, amoebic and bacillary dysenteries, and typhoid-as well as the chronic complaints of rural farmers: schistosomiasis, hookworm, and parasitic roundworms. According to the professor's calculations, these fecal-borne diseases killed thirty to thirty-five million people during the eight years of the war, while the death toll of the war itself was fourteen to twenty million people. ${ }^{34}$ Even accounting for the fact that soldiers did not suffer all of these deaths, adding vector-borne diseases-typhus, malaria, scabies, and relapsing fever-to this list affirms that minuscule microbes caused much more damage to China's fighting force than did Japanese bayonets and ordnance. ${ }^{35}$

One of the gravest dangers to Chinese soldiers, invisible to the naked eye, caused an insidious death: shigella, the rod-shaped bacterium that produces bacillary dysentery in the human digestive tract. The bacterium's namesake, Japanese physician Dr. Shiga Kiyoshi (1871-1957), had discovered the dysentery bacillus in 1897 while working at Japan's Institute for the Study of Infectious Diseases with its founder, Dr. Kitasato Shibasaburo (1853-1931), who himself had worked with Robert Koch. ${ }^{36}$ Characterized by abdominal cramps, fever, and violent, unstoppable, bloody diarrhea, dysentery desiccates its victim to death in a matter of days. ${ }^{37}$ Passed via fecal-oral transmission, shigella flourishes in the overcrowded, unsanitary conditions often present during war, even far away from the battlefield. Liu Feng, when recalling his experiences as an eleven-year-old apprentice in a Chongqing arsenal, said, "My greatest fear was diarrhea. In Chongqing I would shit until I got dizzy. It was so bad that by nighttime I couldn't see anything." ${ }^{38} \mathrm{Cur}-$ rently treated with sulfa drugs, antibiotics, and the penicillin derivative ampicillin, created in 1961, bacillary dysentery was in the 1930s and 1940s often untreatable and frequently fatal. ${ }^{39}$

Cholera, another lethal disease that kills through chronic diarrhea and desiccation, also plagued Chinese soldiers during the war. Difficult to treat without antibiotics or immediate oral rehydration, it is caused by an agent, vibrio cholerae, that lives in water or food contaminated with human waste and can kill a person in a matter of hours. The victim first suffers nausea, vomiting, muscle cramps, and headache; impending death manifests itself in bluish skin and sunken eyes. Since the disease plagued both soldiers and civilians, military and civilian health organizations did joint prevention work. The NHA performed frequent cholera vaccination drives in which soldiers and prospective soldiers received priority, MRC hygiene engineering teams separated latrines from drinking water and disinfected wells, and military field medics learned how to devise a simple saline solution 
(or a sugar solution if no salt was available) for rehydration therapy. Yang Wenda recalled seeing the greatest number of corpses at any point of the war during a cholera epidemic in Nanchang. He and his MRC coworkers had to bury the bodies in mass graves of fifty to sixty corpses each, with a sprinkling of lime on top as a disinfectant. ${ }^{\circ}$

Recognizing that most field medics had undergone only brief training, the NHA produced portable, pocket-size pamphlets for military medics and emergency first aid nurses working on the front lines. Written in simple text without illustrations, these pamphlets provided detailed information on the prevention, identification, and treatment of all nine legally notifiable contagious diseasestyphoid fever, typhus, dysentery, smallpox, plague, cholera, diphtheria, contagious cerebral meningitis, and scarlet fever-as well as other common diseases such as scabies. The 1940 NHA pamphlet on cholera recommended traveling with a small quantity of bleach powder to disinfect drinking water, since soldiers routinely "drank from paddy fields." ${ }^{11}$ The pamphlet also detailed proper management of a cholera patient's feces, though judging by the descriptions of military hospitals, sanitary feces management must have occurred rarely among sick soldiers. ${ }^{42}$ Most of the suggested measures would have been impossible to follow in the field. For example, in many field hospitals the water supply barely sufficed for cooking and soldiers had to forgo bathing, so the medics certainly could not have washed the bedding each time it was soiled. Zhou Meiyu recalled that many a thousand-bed field hospital, unable to keep all thousand quilts clean, simply kept them in a closet and forced soldiers to sleep without bedding until an official came for an inspection. ${ }^{43}$ A soldier suffering from cholera or dysentery would have soiled the straw or cot on which he lay multiple times a day, requiring the labor of many staff to maintain hygienic standards. Yang Wenda recalled addressing this problem by cutting holes in soldiers' cots and placing bedpans underneath so that sick soldiers unable to walk to the latrines could relieve themselves without soiling their bedding. ${ }^{44}$

By the spring of 1940, malaria and gastrointestinal diseases were demonstrably the primary killers of soldiers. Malaria had already proven its lethal might: in August 1938 "whole regiments were infected with malaria and an entire division stopped in its tracks." The MRC responded by distributing more than fifteen million quinine tablets in that single year of 1938. Nor did the danger diminish: a study conducted at the fourth EMSTS center in southeastern Sichuan from July 1943 to June 1944 recorded 10,760 cases of dysentery and 24,160 cases of malaria among troops in that area alone. Even partial data from the NHA showed a total of more than 1.7 million cases and nearly nine thousand malaria deaths between 1940 (the year data collection began) and 1945, as well as a huge spike in 1946, when the NHA recorded nearly a million cases and four thousand deaths. Nonetheless, the partiality of this data showed clearly when the United Nations Relief and Rehabilitation Association (UNRRA) produced its survey of annual communicable 
disease infection rates in China in July 1944, and estimated 21.3 million cases of malaria per year. ${ }^{45}$

Malaria illustrated the blurred lines between civilian and military health. With both mosquito nets and quinine in short supply, malaria spread even to the cold northern provinces when disease-ridden soldiers moved their battle lines there. Meanwhile in the southwestern province of Yunnan, where malaria was endemic, the disease incapacitated nearly 30 percent of the two hundred thousand laborers who built the Burma Road by hand; once again the civilian NHA and the military MRC collaborated to control it. In 1941 the National Institute of Health trained 138 male sanitary engineers in Chongqing, Guiyang, and Kunming in mosquito eradication techniques, which included draining ponds, covering standing water with kerosene to kill larvae, administering prophylactic drugs, and teaching people how to cover themselves while sleeping. Later, when the United States finally joined the war and had troops stationed in Yunnan, US Army personnel sprayed DDT across the area. ${ }^{46}$

The tiny louse joined the mosquito as a formidable foe. Typhus, relapsing fever, and other louse-borne diseases accumulated a tremendous death toll during the war, just as they had done across Europe during World War I.47 Body lice wreaked havoc for the very simple reason that soldiers had little access to clean clothing and bedding; the NRA did not have the capacity to issue foot soldiers with more than one uniform. One soldier recalled that his single uniform "very quickly became infested with lice." ${ }^{8}$ Staff in the MRC, NHA, and AMA recognized the severity of the situation and launched a war within a war against the minuscule and multitudinous louse. In September 1938 they began a delousing, bathing, and scabies (DBS) program to build mobile stations where soldiers could take baths, wash their clothes, and get haircuts. By June 1940 over two hundred such stations served soldiers around the country. ${ }^{49}$ The showers had the added benefit of combatting scabies, another scourge of a dirty soldier and one that affected 70 percent of patients reporting to MRC health stations in 1938. In the ninth war area, by March 1943 bathing reduced the incidence of scabies from 90 to 10 percent. Proper cleaning of a soldier's lice-infested uniform required multiple steps. Liu Yongmao, the leader of the MRC environmental hygiene team, demonstrated to his staff that even when a soldier's winter jacket appeared clean after washing, thousands of lice still hid in the seams. Liu would run a hot clothes iron along the seams, then use a broom to sweep all the dead lice into a pile to show just how many more had been hiding inside. Zhou Meiyu and Yao Aihua both remembered that soldiers' body lice would attempt to crawl onto nurses while they tended to the wounded, so nurses tied the ends of their sleeves and covered their collars with bandages dipped in Vaseline to prevent the lice from getting traction. Nonetheless, "even with these kinds of careful protections, there were still incidents of contagion, so we did lose several nurses." ${ }^{\circ}$ This gruesome reality underscores the fact that 
nurses not only accepted low pay and tough working conditions, but also risked their own lives to save the lives of others.

Because bacilli and bombs do not discriminate among their victims, the war created a certain degree of "social leveling" that opened the possibility for elites to empathize with their social inferiors through the common experience of suffering. Socioeconomic privilege could not entirely contain the traumas of war; even middle- and upper-class people lost their homes and family members to air raids and disease, especially as diseases expanded their temporal and spatial territory ${ }^{51}$ Refugees, enemy soldiers, and Chinese troops moved long distances, taking diseases with them. ${ }^{52}$ Chiggers (trombiculid mites), for example, traveled with the Japanese army, expanding the range of scrub typhus all the way from Japan to China's Yangzi Valley and other regions of the Pacific War. ${ }^{53}$ Epidemics began to follow new routes and timetables. In May 1941, Dr. H. W. Tseng of the Chongqing Methodist Union Hospital (Chongqing Kuanren Yiyuan) reported that he had seen "winter epidemics occurring in summertime," and that contagious diseases spread "far more easily than in peacetime." ${ }^{44}$ Chongqing factory worker He Qiuping recalled that "cholera became rampant because of the Japanese bombings." 55

Yet social leveling had its limits, and the poor undoubtedly paid the overwhelming cost of the war. Corruption in the military recruitment system placed the greatest burden of soldiering on poor families because the wealthy had many means of evasion: purchasing the services of a replacement; bribing someone to falsify census records (usually sons' ages); dividing family property prematurely to make all sons heads of household and thus ineligible for the draft; putting a son in school; sending a son to work in the city or a different village where he was not on the population rolls and could evade the local baojia head during conscription rounds; bribing recruitment officials; making one's son a recruitment official; or defending oneself with guns. Poor men were not entirely without means of defense: where the rich used guns, the poor used knives; and where the rich used bribes, the poor used their legs to run away from conscription gangs. ${ }^{56}$

Nonetheless, the majority of conscripted foot soldiers were poor and already in a state of compromised health before they even got to the battlefield (see figure 13). Sichuan supplied the greatest percentage of soldiers for the War of Resistancegiving a total of 3.4 million-and Chongqing shouldered a hefty share of this burden. ${ }^{57}$ Rural Sichuan had very high rates of hookworm and schistosomiasis, and all of rural China had high rates of chronic gastrointestinal parasites, all of which compromise the body's ability to absorb nutrients from food.$^{58}$ In 1941, Minister of Health Jin Baoshan wrote that only 40 percent of four and a half million conscripts proved physically fit in a health examination, and 50 percent of these would likely develop an illness before getting to the front. ${ }^{59}$ In one group of new conscripts bound for the ninth war area, 78 percent died in a dysentery outbreak due to malnutrition and lack of medicines. ${ }^{60}$ 


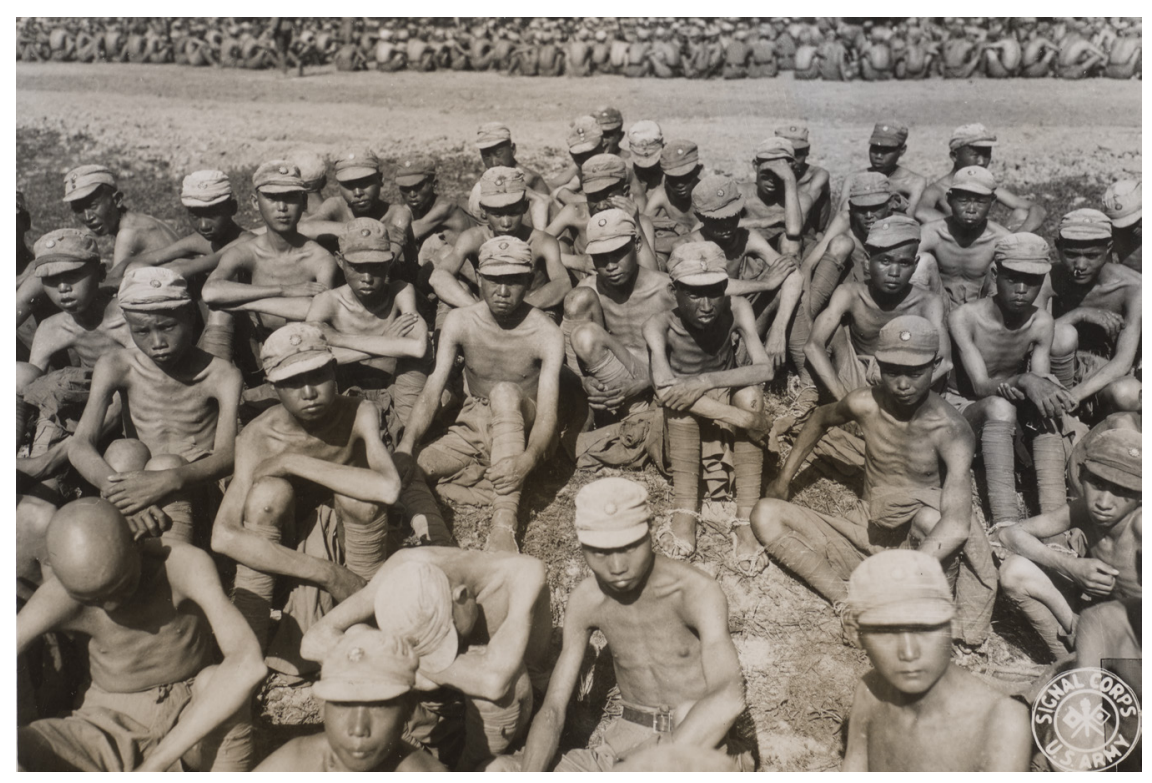

FIGURE 13. New soldier recruits already looking famished. Photo taken by the U.S. Army Signal Corps. Box 85, folder “Soldiers-Wounded." ABMAC Records. Rare Book and Manuscript Library. Columbia University.

New conscripts often had to march hundreds of miles just to get to their recruitment centers, then further to the battlefield. Traveling such distances often meant that soldiers arrived in a state of exhaustion in areas of the country where strange climates harbored diseases to which they had no acquired defense. ${ }^{61}$ They might also lack proper clothing for the climate to which they marched; soldiers frequently wore threadbare uniforms and straw sandals that chaffed their feet, or no shoes at all. Superintendent Yang Wenda recalled treating many foot soldiers from Guangxi while supervising an MRC unit in Nanchang, Jiangxi. Yang stated that "these southern soldiers had no idea what winter was like in Beijing or Shanghai, so they traveled north in grass sandals and got frostbite. By the time they came back many of them had lost their toes and had to walk on the balls of their feet." ${ }^{62}$

\section{LONELY SOULS AND WILD GHOSTS BURIED WITHOUT A COFFIN}

The story of sixteen-year-old Pan Yintang illustrates how dangerous life in the Chinese army could be for the average foot soldier from a poor family-fourteen million of whom were conscripted throughout the war-as well as the suffering that ignoble death and improper mortuary treatment inflicted on soldiers. ${ }^{63}$ 
In 1938, Pan and 280 other young men fell victim to a conscription gang. The gang captured the men from Pan's home village of Shizi and nearby villages in Dazhu County, Sichuan. A farming boy accustomed to handling livestock, Pan likened their seizure to a farmer capturing pigs for slaughter. ${ }^{64}$ This metaphor proved rather prescient, since most of his fellow captives never returned home.

The conscription gang threw Pan Yintang and the other captives into a desperate war. In raw numbers, the adversaries appeared to be evenly matched: by November 1937, China's NRA had 1.7 million troops in service but no reserves, while the IJA had six hundred thousand men in active service and nearly a million in reserve in the nearby Japanese colonies Manchuria and Korea. At its height the NRA fielded over four million soldiers, while the IJA eventually fielded 1.65 million troops in fifty-one divisions. ${ }^{65}$ The NRA had to push more troops into battle because the Japanese had notable advantages in leadership, training, organization, munitions, and military hardware (chiefly tanks and planes), though China did receive crucial air assistance from the Soviet Union and later the United States. ${ }^{66}$ The IJA therefore consistently inflicted greater casualties with fewer troops: in the Battle of Shanghai (August 13-November 12, 1937), Chinese casualties mounted to 187,200 , while fewer than 10,000 Japanese soldiers died and a little over 30,000 sustained wounds. During Operation Ichigo, Japanese soldiers killed twenty to forty Chinese soldiers for every one loss of their own. ${ }^{67}$ After conquering nearly all of China's coastal cities in the first few months of the war, including the capital, Nanjing, the Japanese Army had logged only 100,000 casualties. Meanwhile, China had suffered so many fierce defeats that reporters elided details in order to sustain morale. ${ }^{68}$

NRA leaders, unable to avoid the facts, began to make rash decisions that actually increased Chinese civilians' suffering. In December 1937 Chiang Kai-shek abandoned Nanjing rather than defend it, and then General Tang Shengzhi did the same rather than fulfill his sworn promise to Chiang to defend the capital to his death. This dual abandonment left civilians defenseless and at the mercy of an angered and rapacious enemy in an event that has been memorialized as the "Nanjing Massacre" or "Rape of Nanjing." ${ }^{9}$ In November 1938 General Xue Yue, fearing a Japanese invasion of Changsha, preemptively burned the city to the ground rather than yield it to his enemy, thus becoming the city's destroyer rather than its protector. ${ }^{70}$ Wishing to stall the Japanese advance on the first provisional capital of Wuhan, Chiang Kai-shek ordered the destruction of the dikes holding back the mighty Yellow River at Huayuankou in June 1938, killing half a million people and rendering another 4.8 million refugees. This disastrous act delayed the Japanese advance by only five months, and Wuhan fell in October $1938 .^{71}$ It also characterized the Nationalist state's extractive relationship with the natural environment, which led to immense ecological devastation throughout the war. ${ }^{72}$ Though trading space for time came at such a great cost, space was indeed China's major advantage. Continually moving his troops and his administration across 
vast distances, Chiang trapped his Japanese adversaries in the "China quagmire" and bought himself some time to revitalize his armed forces.

The NRA sorely needed a revitalization. The losses at Shanghai alone had included over 70 percent (thirty thousand) of the German-trained and highly loyal officers in Chiang's army. ${ }^{73}$ The remaining disloyal officers could cause serious problems. In the famous battle of Taierzhuang (March 24-April 7, 1938), General Li Zongren expressed his Janus-faced patriotism by refusing hospital access to soldiers from his commander Chiang Kai-shek's Central Army and offering treatment only to soldiers from his own power base of Guangxi Province. ${ }^{74} \mathrm{Al}$ though feted for bringing his countrymen their first major victory in the war, General Li confirmed Chiang's suspicion that divisions within his own command could fracture the power of his army and directly endanger soldiers' lives.

Soldiers of course already faced myriad dangers, one of which is well reflected in Pan Yintang's story: their utter lack of training and preparation. Pan and his fellow conscripts first traveled to Guizhou, then to Kunming, where they received an extremely rudimentary training. He recalled that "each man was given a gun and three bullets, and we tried out the guns a bit, then we were considered ready to go to the battlefield." From there they went to Burma, where Pan and his fellow troops faced starvation. He recalled that they received no pay and meager rations, so they stole pumpkins, cucumbers, and beans from the farming fields and ate them raw. Still, they were frequently dizzy and nearly blind with hunger. ${ }^{75}$ Napoleon Bonaparte is credited to have said, "An army marches on its stomach." As Pan Yintang's experience demonstrates, China's army had very little to march on. Though a particular problem in the Burma campaign, chronic malnutrition plagued all Chinese troops. While on paper a soldier had adequate rations-twenty-four ounces of rice per day, a sufficient amount of salt, and one pound of pork per month-in reality many officers resorted to corrupt practices to squeeze these rations out of their men and take the lion's share for themselves. Soldiers who did receive field rations often had little but uncooked rice kernels, so they frequently stole food from civilians as they passed through villages. ${ }^{76}$ In 1945 US General Albert C. Wedemeyer wrote in a report to Chiang Kai-shek that "as [Chinese soldiers] march along they turn into skeletons; they develop signs of beriberi, their legs swell, and their bellies protrude." 77 Wedemeyer ended his report with a reference to the profound corruption within the Nationalist military-a severe problem that made Chiang Kai-shek irate. Ultimately, Chiang ordered an extensive investigation and the executions of the head of the conscription service, Lieutenant General Cheng Zerun, as well as the commanding officer of a particularly egregious recruitment camp. However, Chiang acted too late to save soldiers from abuse-in July 1945, one month before the war's end..$^{8}$

Pan and his companions had been conscripted into the Chinese Expeditionary Force that fought with US General Joseph Stilwell in the disastrous 1942 Burma 
campaign. Despite General Stilwell's ability to spin the story to his advantage such that most English-language histories to this day paint him a hero, the campaign ended with the defeated Stilwell abandoning the Chinese troops in the Burmese jungle, where most died of starvation and disease. ${ }^{79}$ Even during the second Burma expedition in 1944-Stilwell's attempt to massage his bruised ego-four out of five Chinese soldiers sustained combat wounds or died. Fortunately for these wounded men, substantial medical aid from the US military provided sufficient medical care for 60 to 70 percent of the wounded to return to battle (where they once again risked their lives in combat).$^{80}$

In 1942, Pan Yintang and his fellows in arms could not rely on such aid. Their death toll mounted; of the 280 men taken from Pan's county in Sichuan, 178 (64 percent) perished of starvation, disease, or battle wounds. In the end only 35 made it out alive and well, while another 67 returned home disabled. Pan ultimately decided that in war most of the conscripted men "became lonely souls and wild ghosts" who died far away from home and received but a summary burial..$^{81}$ Soldiers frequently suffered this fate, even if they died on the Chinese side of the Himalayas. Yao Aihua recalled that "at first when the wounded started to die they would get a coffin of thick wood; later on as the death toll began to mount, the coffins grew thinner and thinner, until in the end they received no coffin at all." ${ }^{2}$

The pain of witnessing improper treatment after death is quite close to universal in human societies, but it had particular poignancy for Chinese soldiers. ${ }^{83}$ In traditional Confucian culture, the idea of luan, or "internal confusion and chaos," was "feared more perhaps than the external invading army," and luan is exactly what death produces - a tear in the fabric of the social, an unstable (if temporary) proximity of this world to the afterworld, an opportunity for the dead to seek vengeance against the still living if they are improperly guided to safe harbor in the hereafter. ${ }^{84}$ Funerary ritual, properly performed by the right people in the proper space and time, fulfilled the immensely important job of safely guiding the dead to a settled life-in-death in a parallel universe. ${ }^{85}$ Those who died away from their families and communities, for whom no one could perform the requisite rituals, suffered not only an ignominious death but the existential angst of an uncertain postmortem existence.

Properly speaking, the dead themselves did not feel this after their passing, for as corpses they could feel nothing, but the soldiers who witnessed so many of their comrades' bodies treated like so much detritus likely dreaded that such a fate might befall them as well. Soldiers who survived also might easily have feared the power of the "wild ghosts" that their fallen comrades had likely become. Such wild ghosts-people who died at the wrong time or in a manner that superseded normalcy, such as during warfare-had the potential to disrupt the safety of the living. At least in northern China through 1945, "[t]here was generally a pervasive concern with the dangerous power of the spirits of those who had died by violence." Such individuals could easily feel wronged by the unnatural 
circumstances of their deaths, remain unsettled by the lack of proper funerary ritual, and use their powers as "unhappy spirits" to disrupt the lives of those who remained on earth. ${ }^{86}$ Particularly those whose bodies suffered significant trauma in death, and therefore lacked a complete body with which to enter the afterlife, became "demons" for whom "even access to hell was denied." ${ }^{87}$ The living therefore felt a profound responsibility to honor the dead with proper mortuary ritual and burial, and suffered when circumstances prevented this. During the war they also suffered in the absence of secure knowledge of their relatives' whereabouts; the NRA had not systematized its tracking and sometimes recorded soldiers as "without a trace" (shizong) - a word whose simplicity belies the torture that this lack of closure entailed for family members. Famous author Lao She passed devastating months wondering about his mother's whereabouts, of which he wrote, "[P]eople whose mothers are alive have secure hearts. I feared, feared, feared that a letter from home would tell me that I was now a plant without roots." ${ }^{38}$ For some of the people who died while sojourning in Chongqing, neighborhood associations and charitable organizations stored their coffins throughout the war and worked to return them to the deceased's hometowns after victory. For the soldiers and others who followed the Nationalists to Taiwan, repatriation of remains to the mainland became impossible, and banishment to "a land where none of your relatives are buried" caused psychological torment that set their very identity on edge. ${ }^{89}$ During the Cultural Revolution (1966-76), when all forms of traditional culture in mainland China were under siege, "one of the most intense anxieties experienced by survivors of the dead was their inability to attend properly to the traditional rituals of death and dying."9o The same situation pertained during the War of Resistance. So profound was this pain for Pan Yintang that many decades after the war ended, he encapsulated his experience as bearing witness to the men around him as they "became lonely souls and wild ghosts."

\section{ZHOU MEIYU AND THE ROLE OF WOMEN IN MILITARY MEDICINE}

As with civilian nursing, military nursing expanded more dramatically than any other sector of military medicine during the war. Extrapolating from May 1948 data, at the end of the war China had 10 dentistry schools, 25 pharmacy schools, 91 medical schools, and 171 nursing schools. ${ }^{91}$ The dramatic expansion in nursing could be described as an "intentional accident" in that it arose from a confluence of factors both planned and unplanned. The Nationalist government had devoted inadequate funding and preparation to its military medicine system prior to the war's outbreak but had also instituted mandatory nursing training for high school girl students that, sure enough, provided a pool of cheap labor when the 
crisis hit. No one could have predicted exactly how many hospitals would fall into Japanese hands, but once they did the AMA called in civilian help and authorized the creation of two additional military medicine organizations under independent leadership: Dr. Lim Kho Seng's Chinese Red Cross Medical Relief Corps (MRC), founded in August 1937 to create a mobile medical service to staff the more than two hundred AMA hospitals spread along the front lines, and the Emergency Medical Service Training School (EMSTS), founded in May 1938 to provide shortterm, intensive training in medicine and epidemic prevention to fulfill personnel needs within the rapidly expanding civilian and military medicine systems. ${ }^{92}$ Female nurses worked in all of these organizations, as well as in a variety of civilian volunteer groups, and did the most work to care for civilians and soldiers amid the trauma of war.

The rapid and, to civilians, rather unexpected advance of Japanese troops created an immediate crisis in the medical system, made all the more urgent due to the Nationalist government's poor preparation. At the beginning of the war, the AMA had only one doctor per seventeen hundred soldiers, and thousands of inadequately trained medical personnel. The total of three and a half million soldiers who served during the duration of the war could count on only 1,922 military doctors. ${ }^{93}$ Although war began in July 1937, there were no regulations governing the transport, treatment, or reenlistment of wounded and ill soldiers until September, and field hospitals and triage centers could not be established throughout the war zones until the founding of the Central Management Office for Wounded Soldiers (Zhongyang shangbing guanlichu) in October. ${ }^{94}$

The wounded therefore quickly overwhelmed all available facilities. Famous author Xie Bingying, who organized women's volunteer medical corps in 1927 for the Northern Expedition and in 1937 for the War of Resistance, recalled of the wounded soldiers streaming in from the Battle of Shanghai (August-November 1937):

$[\mathrm{T}]$ hey were lying crowded together in every room and even on the steps in the central courtyard. ... Some had legs or arms severed by explosions. Others had lost half their brains in bomb blasts. Some had been hit in the stomach by machine guns and their small intestines were spilling out. Some had bullets still lodged in their flesh, and they cried out day and night from the pain. Some were missing two-thirds of the skin and flesh on their thighs. Some had wounds in which multitudes of maggots grew. Some had only a single tendon left in their hands. ${ }^{95}$

Wounded soldiers and the nurses who tended to them confronted gruesome scenes like this one throughout the country. Such experiences were common in military nursing; during World War I, Russian military nurses "were bombarded with numerous dramatic, indeed traumatic, sensory perceptions" and often felt "immediately and strongly repelled" by the sights and smells of wounded bodies. ${ }^{96}$ Yet military nurses were trained not to make the "disgust face" that psychologists 
claim to be universal; they posit that humans in all societies and animals alike exhibit scrunched eyebrows, a curled upper lip, and a physical jerk away from the offending item. ${ }^{97}$ In China as in Russia, this telltale sign would have affirmed the soldiers' physical repulsiveness, but as chapter 2 explains, nurses were expected to perform the emotional labor of smiling through difficult work in order to communicate care.

Japanese troops advanced far more rapidly than new personnel could be trained, so the government sought another source of medical personnel: female students. In December 1937, the Hubei provincial government required high school girls to undergo nursing training and contribute an eight-hour workday per month in a local hospital. In 1934 the Ministry of Education made nursing a mandatory class for female high school students, added three months of summertime training in 1936, and in 1940 mandated three hours a week of civilian and military nursing training for female students of high school age and up. Also in 1940, Hunan and Sichuan required young women who graduated from high school to work either as rural public health nurses or as military nurses, all the while promoting nationalism and organizing local women for similar work. Between 1934 and 1935, the provincial ministries of education in Jiangxi, Jiangsu, and Anhui provinces duplicated the central Ministry of Education regulation and required female students to study military nursing. Given the limited strength of the Nationalist state, it is likely that many provinces did not follow this regulation to the letter, but some clearly did. ${ }^{98}$

By providing the labor force that the state desperately needed to care for its soldiers, (young) women proved their indispensability to the nation and attained a position of power in constructing it. In late imperial China daughters in elite families were often educated so that they could teach their own children (with a focus on grooming sons for the civil service examination). In the Republic advocates of girls' education leveraged its benefit to the nation to argue their position, claiming that uneducated and bound-footed girls (the "Sick Women of East Asia") made the whole nation weak. ${ }^{99}$ Whether for the patriarchal family or the patriarchal nation, women gained access to education not because it directly benefited them but because it benefited a larger social collective. This simultaneously put women at a disadvantage-always required to put others before themselves-but also placed them at the fulcrum of constructing this collective. During the War of Resistance women became conduits of state power, even as young students.

High school students clearly had some agency in how they answered this government mandate. For example, when students in Zhejiang found their nursing courses boring and irrelevant, their principal changed their program to include three hours per week of practicum in a local hospital, which they reportedly enjoyed. Beginning in North China in late 1936, students from Taiyuan (Shanxi Province), Beijing, and Shanghai all organized their own relief teams and went 
to the front to treat wounded soldiers. ${ }^{100}$ In volunteering to nurse soldiers, these high school students were in good company. Prominent women such as Hu Lanqi (1901-94), Xie Bingying (1906-200o), He Xiangning (1878-1972), Jiang Jian (1902-40), and Wu Jufang (1911-99) volunteered across China to care for soldiers and raise funds for the wounded. ${ }^{101}$

These women responded to an acute crisis in military and civilian hospitals in the first months of the war, where the AMA's lack of preparation left wounded soldiers in the lurch. Yao Aihua recalled that in the first few months of her work as a volunteer military nurse, wounded soldiers poured in from the fronts at Shanghai and Nanjing when her volunteer medical team was stationed in Zhengzhou (the capital of Henan Province). The wounded filled all available hospital spaces, and "some soldiers were just out on the streets. Some of them had their intestines hanging out, all bloody and indistinguishable from their other flesh. It was so pitiful!" A lack of ambulances meant that wounded soldiers often traveled by stretcher, rail, or river. ${ }^{102}$ (See fig. 14.) Since the army itself did not always manage the transfer to hospital, troop commanders frequently lost track of their wounded, making it impossible to deliver a soldier's stipend for hospital fees and food and often difficult to redeploy a healed soldier to his original unit. ${ }^{103}$ The sheer number of soldiers moving between hospital and field quickly exceeded the organizational capacity of the military's belatedly established transit system. ${ }^{104}$

The stretcher bearers in figure 14 appear to be civilians. Their clothing bears no mark of medical personnel, and the sparse attire of the man in front indicates a likely status of poor farmer. They may have received payment for their arduous labor, but the mountain's steep decline challenges even the surest-footed among them. A wounded soldier, pressing part of his weight onto a handmade cane and still carrying his rifle, follows closely behind. He may have witnessed his fellow soldier's first moment of agony; if they make it to the hospital, he will hear many more soldiers moan and cry. Someone with a full belly, a whole body, and a camera captured this image, freezing the moment when this limping soldier might have been worrying about whether his buddy would make it, whether he would be able to walk down this mountain, how far they would have to go to get medical care. No field hospital appears anywhere in this wide lens; these farmers are rescuing the two soldiers from certain death. In the absence of a functional state system, they have stepped in to suture the ruptured social contract.

Figure 14 captures a common reality of the war: soldiers often had to travel a long way to get medical care. A military officer explained that even if a medic was stationed nearby, the requisite medical supplies frequently lay at a distance of several hundred $l i$, making even the slightest wound quite lethal. ${ }^{105}$ Wounded soldiers therefore frequently arrived at a hospital in a terribly compromised state. Yao Aihua remembered, 


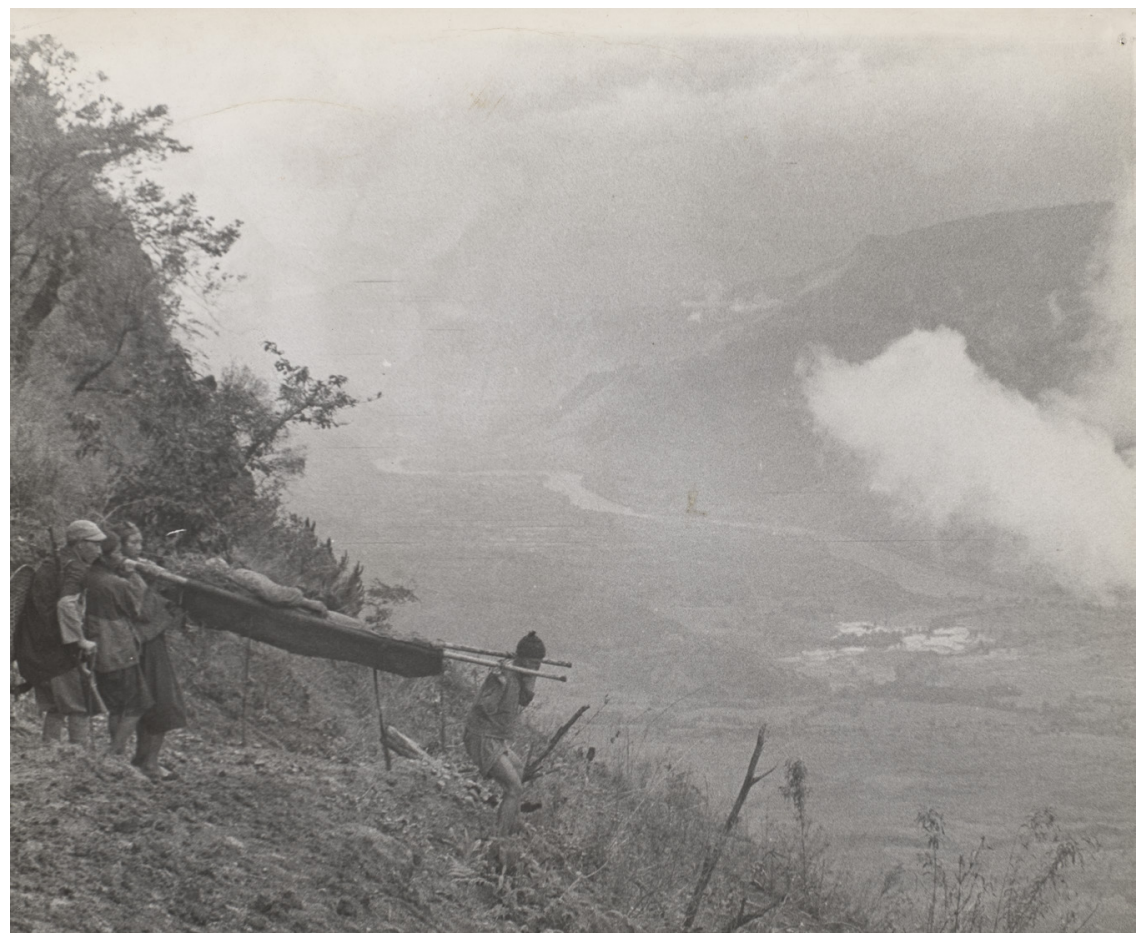

FIGURE 14. Civilians carrying a soldier down a mountain on a stretcher. Box 85, folder "Soldiers-Wounded." ABMAC Records. Rare Book and Manuscript Library. Columbia University.

Because of the sweltering heat, by the time they got to [the provincial hospital in] Baoding most of the soldiers' wounds were filled with pus and maggots and stank to high heaven. With so many wounded close together they gave each other tetanus, and the death rate was very high.... The soldiers' bodies were full of lice, and as we changed their bandages the lice climbed onto us. ${ }^{106}$

The paucity of medical personnel made Yao Aihua's story more common than unique: at the age of sixteen she and all of her middle school classmates answered the call for volunteers from the local Baoding YMCA and Chinese Red Cross and followed their principal to the front after a single week of training in basic first aid. The unending strain of their work, which often began at daybreak and ended after midnight, left Yao so fatigued that at one point she slept through an air raid; her fellow volunteers thought she had died. She also recalled that the shortage of nurses in Zhengzhou meant that they could change a soldier's dressing only 


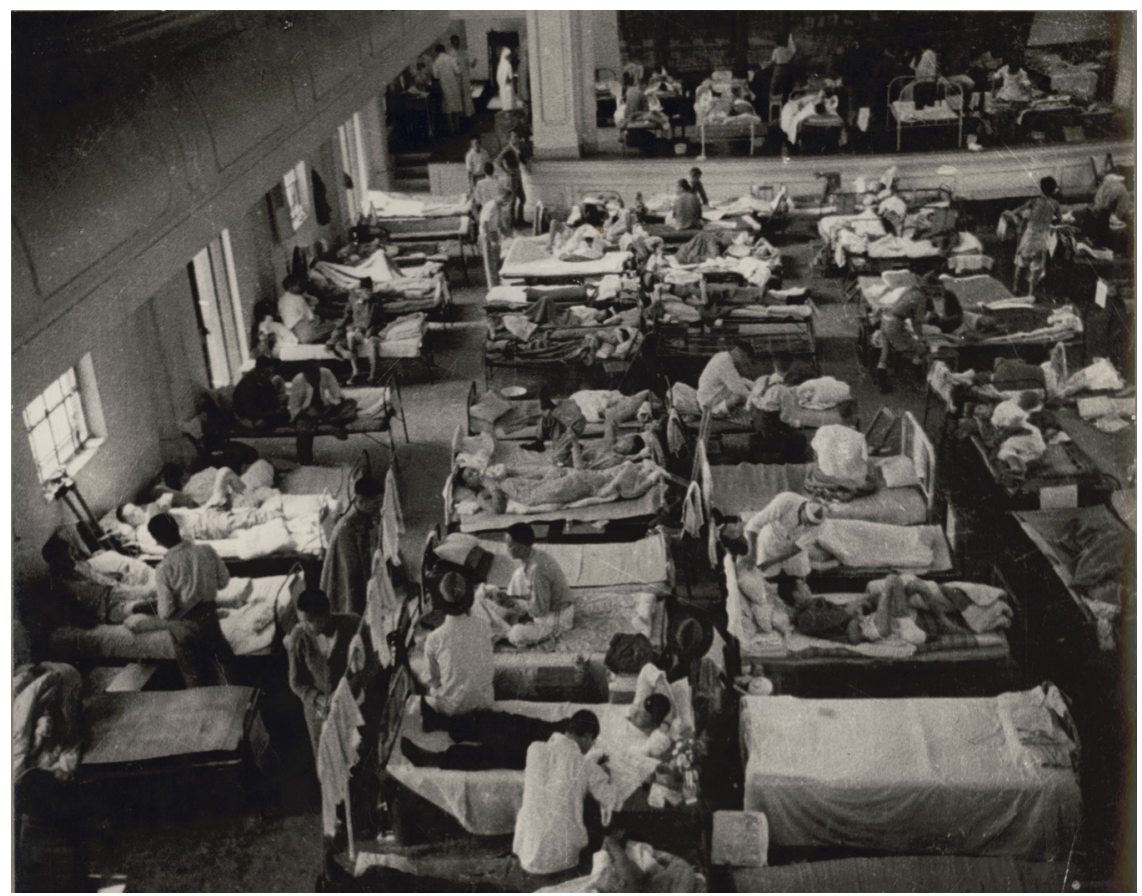

FIGURE 15. As battle lines advanced, hospital staff and patients repeatedly had to flee, and makeshift hospitals were built to accommodate wounded soldiers. This photo depicts one such temporary hospital in a school gymnasium. LOT 11511-7, WAAMD No. 411, U.S. Library of Congress, Prints and Photographs Division.

once every three days, making it difficult to stave off infection, particularly in the summer heat. ${ }^{107}$

Another problem joined the shortage of medical personnel to exacerbate the crisis: insufficient hospital facilities. The Central Hospital of the Chinese Red Cross in Nanjing, which boasted three thousand beds, seven operating rooms, and over three hundred medical staff, fell to the Japanese just one month after it opened. ${ }^{108}$ Medical personnel had difficulty tending to refugees when they had to join them in flight. A great number of hospitals and clinics operated out of temporary quarters originally built for other purposes, and many soldiers ended up in such makeshift hospitals, where they often received inadequate treatment. The temporary hospital pictured in figure 15 had a handful of open beds and housed at least one profoundly emaciated patient (front right).

Demoralized staff who paid little attention to basic hygiene compounded all of these problems. A 1938 Red Cross report stated that "most hospital wards are untidy and the floors messy. Patients' clothes appear pathetic and uncared for. 
Their bodies are unwashed, their hair long and nails uncut, and their quilts covered with lice. The dysentery or diarrhea cases lie in beddings soaked with excreta. ... Many are infected with scabies." ${ }^{109}$ Other reports from field hospitals around the country showed that such conditions were far from anomalous, and this posed a serious danger to soldiers. Battle wounds that began as minor injuries could easily turn lethally gangrenous or infectious due to lack of medical attention or supplies, improper antisepsis procedures, or poor hygiene in a field hospital. Hospitals in recruitment camps had the barest of supplies. Colonel Lyle Stephenson Powell, a US Army medical officer stationed in Guiyang in 1944-45, described one such facility:

I have seen a good many ghastly sights, but I have never seen anything that gave me such a complete turn as did this "hospital." The building consisted of a long, earthenfloored, thatched-roof hut, the sides of which had practically all disappeared, presumably as firewood. Two or three [patients] had old overcoats of some sort pulled up over them; the rest had only shirt, trousers, and either bare feet or straw sandals. For warmth they were lying as close together as possible and were too sick to get up to answer the calls of nature; as a consequence the foulness of the place was beyond belief. As I went along looking at these people I counted several that were dead, some already as stiff as the boards they were lying on. ${ }^{110}$

The destitute conditions of Chinese field hospitals illustrate what a ghastly war can do to an impoverished country. Facing the prospect of improper medical care and callous treatment after risking their lives on the battlefield, many soldiers grew angry. Newspapers reported fights between medical staff and soldiers, and usually blamed the latter. Some hospitals refused service to wounded soldiers. One sympathetic reporter, Ji Hong, told the story of an injured soldier who, having had to hop a railcar by himself to get to an unoccupied city for treatment, was refused aid at all five hospitals he found. Ji also said that hospitals often failed to give soldiers proper food, and that he had met a soldier from Sichuan who had received a meager $\$ 1.50$ in pay after four months of fighting. At one hospital that Ji visited to report on soldiers who had been waiting for three days without treatment, a wounded officer told him that while he could withstand his physical pain, the civilian doctors' brash disregard for his troops' suffering had gravely wounded his heart. ${ }^{111}$

These stories underscore the difference that a caring doctor or nurse could make at a time of vulnerability in a soldier's life. Particularly in the later years of the war, many of the soldiers were teenage boys, often far from home when they sustained a life-threatening battle wound or caught a deadly disease. In face of mortal danger and strident social prejudice, soldiers greatly appreciated and respected nurses who treated them with dignity and kindness. Medical personnel who treated poor men with decency communicated a rare message: your life is valuable, and you are worthy of care. 


\section{TRANSFORMING “BAD ATTITUDES”: EMOTIONAL LABOR AND NECROPOLITICS}

Female nurses' first message to convalescing soldiers communicated valorization and care. The assumption that men must fight held strong even though the country they defended so often failed to acknowledge their basic human dignity. At least, this held for poor men; many a rich man thought nothing of dodging his responsibility. Nurses could therefore make a tremendous difference in the lives of poor soldiers by giving them both medical care and human caring. They worked within a system directed mostly by men, and among some male military nurses and men in other medical roles (frontline medic, stretcher bearer, physician), but women did the most to provide the emotional labor that helped soldiers to heal.

At the same time, analysis of women's emotional labor helps to explain a remarkable aspect of the War of Resistance, which it shares with other "great wars" of the twentieth century: "the colossal numbers [of people] persuaded to lay down their lives." ${ }^{\prime 12}$ Women simultaneously provided affective care that encouraged soldiers to feel bonded to the nurses, and employed that bond to send them out into battle once more. In this manner they supported the nation as a "community of death." ${ }^{13}$ Nurses frequently employed didacticism to play their role in affirming the supremacy of the nation's needs over the needs and desires of individual soldiers. They looked to upper-class women's groups for models, and to media representations of Song Meiling as their leader. A heavy class politics saturated these media and taught a generation of women to treat male soldiers as their students and as objects of reform.

The communion of female providers and male recipients of care placed women in positions of authority and power. One young nurse's impassioned speech beautifully illustrates the power differential, deriving from her social class, that existed between herself and the soldiers under her care. Her choice of words also illustrates how much her own sense of fulfillment stemmed from her belief that she had the power and responsibility to educate the soldiers to behave differentlyprecisely what Song Meiling instructed women to do in their volunteer work.

At the time most wounded soldiers had a poor understanding of the war, so very few of them wished to return to the front lines after they healed. This was a very dangerous situation, since if they returned they would undoubtedly be more experienced than fresh recruits. So we used every opportunity to turn their hearts, talking with them, doing propaganda work, singing war songs, and we would slowly transform their bad attitudes into resolve; they would eventually tell us that once they got better they'd go back to fight the enemy. ${ }^{114}$

As much as nurses' medical treatments crossed class lines to create emotional intimacy, their attitudes and language could redraw those lines in stark terms. 
This nurse's words clearly delineated her belief in her power to "transform bad attitudes," "turn hearts," and educate soldiers out of their "poor understanding of the war."

In reality, convalescing soldiers wished to return home precisely because they understood the conditions of war better than did the nurses stationed at hospitals in the rear, though nurses stationed at the front of course witnessed and sometimes personally experienced its horrors. Dreams of desertion rather than of battlefield victory occupied the mind of many a soldier. Poorly trained, ill equipped, underfed, and frequently underage, the average Chinese soldier had little chance of surviving combat against the troops of one of the world's most powerful armies. Particularly in the later years of the war, when press gangs rather than recruiters delivered most of China's troops to the front lines, they also had little ideological attachment to the role and looked upon military service as a death sentence. ${ }^{115}$

Male military nurses exacerbated the problem because they tended to browbeat convalescing soldiers, and this mistreatment made their patients feel uncared for and less willing to risk life and limb once more by reporting back to their units. Major General Zhou Meiyu discerned both the problem and how to solve it. She sent female nurses to the hospitals housing soldiers who had a chance of recovery and returning to duty. She instructed these women to treat the soldiers with tenderness and use their attentive care and encouraging words as a means of shaming the men back into uniform. In her oral history interviews, Zhou explained that every time some soldiers had healed and were soon to be sent back to the front, the hospital would ask Zhou to send in some of her female nurses, because there would always be a few soldiers who would get angry and start to fight, arguing that they were not fully cured. The nurses who followed Zhou's training spoke encouraging words to these angry soldiers, which helped to calm them down. ${ }^{116}$

Zhou's astute use of women's emotional labor to increase the fighting power of the NRA accords with the fact that "reciprocal injuring is the obsessive content of war ... [but] its centrality often slips from view." 117 Not merely "angels of mercy" who soothe and console, female nurses also play a central role in the system of mutual injury, for an "effective medical system ... contribute[s] to war precisely by contributing to one side's ability to out-injure the other side." ${ }_{118}$ In wartime China, female nurses repeatedly sent their own healed patients back to face Japanese soldiers who had been schooled in anti-Chinese racism and trained to treat their adversaries like beasts. ${ }^{119}$

Despite their work in exposing their own soldiers to harm, female nurses celebrated their healed charges' decision to return to battle with send-off parties. In one such case at a bus station, the nurses overheard a soldier saying, "Those girls treated us extremely well. If we don't return to the front to kill the enemy we're not doing right by our country." This comment led one nurse to declare, "Once we heard this, how happy we were! We redoubled our efforts, and we learned a 
valuable lesson: the work of educating soldiers was just as important as the work of healing their wounds." 120 This "education" consisted of self-conscious performance of heteronormative femininity - the embodiment of tender care-so as to shame men into accepting the duty of heteronormative masculinity: sacrificing one's own life for that of the nation.

This report therefore confirms that many women accepted their role in supporting the Nationalist state's exercise of necropolitics. In other words, they saw one important aspect of wartime womanhood as the ability to prop up the nation's fighting men and urge them to sacrifice themselves in military service. Yao Aihua articulated this even more pithily (as quoted in this chapter's epigraph): “We all thought, 'We must work ourselves to the bone; saving one more wounded soldier is like killing one more devil [Japanese soldier]!"”21 Yao may have learned such words to describe her experience as a military nurse in part by reading the autobiography of Xie Bingying, in which Xie declared that their motto for relief work was "Saving one soldier is like killing one enemy" ${ }^{122}$ Regardless, a female nurse's necropolitical power stemmed not from her ability to effect death for members of the invading army (politics as usual), but rather from her power to send her own country's soldiers back to the front lines, where they once again stared into the yawning mouths of early graves.

Her power relied on heteronormative gender roles that posited heterosexual attraction as the basis for male-female relationships and therefore placed women in a position of seductive power over men. The centrality of this relationship in Chinese gender roles dates to the early twentieth century, when the social space for male-male bonds shrank after the 1905 abolition of the civil service examinationthe chief means for elite men to form all-male social networks-and globally circulating theories about evolution and human social organization assigned primary importance to the male-female procreative bond. Chinese theories of modern personhood formed at this time, leading people to "rethink gendered social relations as heterosexuality." The normalization of the male-female sexual bond, signaled in the language of pursuing women's education and "natural feet" for the sake of healthy progeny-that is, in the language of the "Sick (Wo)Man of East Asia"-eclipsed the social visibility and permissibility of nonheterosexual relations. In other words, "social theories of eugenic heterosexuality sought to reorder organic life around the procreative couple at the expense of the bond of filial father and son and brothers." ${ }_{123}$ For both men and women, then, innate sexual difference and heterosexual identity based on the presumption of that difference lay at the foundation of modern selfhood.

As the new standard presumed to be universal, heteronormativity served as the fulcrum around which ideas about producing life (strengthening the "Sick Woman" to bear strong children) and about taking life (strengthening "our" soldiers so that they can kill more "enemy" soldiers) danced around and transformed into 
one another. The Nationalist state's necropolitics mobilized men and women into distinct and directly contrasting social roles that nonetheless worked toward the same goal of building a strong nation and defeating the Japanese army. Just as a great part of the power of modern warfare lies in people's ability to obfuscate its violence, heteronormativity in the medical workforce posited women as the caring, nurturing, supporting partners in the creation of mass-scale death who could coerce, cajole, and shame men into killing more ruthlessly. This system presumed that heterosexual identity - which placed primacy on maintaining one's attraction and attractiveness to members of the opposite sex-would secure women's psychological effect on men. Therefore, the more a woman embraced her role of strengthening the nation through nurturing its progeny (i.e., nursing, but also midwifery and childbirth), the more a fighting man felt compelled to embrace his work of killing on behalf of the nation. Military medical infrastructure extended the caring arm of the state, which in turn supported its killing arm: the exercise of necropolitics relied on women's healing as surely as it relied on men's murder.

Nurses may not have fully understood their role in obscuring the bald facts of military violence - that war's purpose is "to alter (to burn, to blast, to shell, to cut) human tissue" - because direct recognition of this fact requires a certain measure of fortitude. They nonetheless played a most essential role, for "the perpetuation of war would be impossible without the disowning of injuring." ${ }^{124}$ While ample evidence suggests that many women yearned for the chance to prove their mettle in military nursing, their primary motivation could just as easily have been to provide succor to their own as any explicit desire to harm the enemy. Regardless, many women celebrated their ability to employ what they believed to be their uniquely feminine attributes: the caring touch of gentle nursing; a patient ear to quell a soldier's anger; rousing words to encourage a frightened boy to resume his manly duty on the battlefield. One nurse worked for two years without a single day of rest while she moved with the battalion she served, from Zhejiang to Jiangxi to Hunan to Guangxi provinces. She believed that the most crucial lesson these two years taught her was how to have patience with the soldiers so as to understand their "hardened hearts," gain their trust, and boost their morale. She wished to publicize the fact that "now no one dares refuse to return to the front," and clearly felt proud of her ability as a military nurse to populate her country's battle lines. ${ }^{125}$ Another nurse revealed how attractive military nursing appeared vis-à-vis civilian nursing. She said that she had come from a missionary hospital in Shanghai, where she and her coworkers "were all depressed" because they wanted to come to the interior to serve in Free China but had family obligations, economic limitations, and no contacts to help them along the way. She stated, "If the government could establish networking organizations and escort them into the interior, I'm willing to bet that many nurses would come." ${ }^{126}$ 
She may have been right, since the famous authors Ding Ling and Xie Bingying, acting on their own and without government aegis, had little trouble recruiting women to go to the front as volunteer nurses. Ding Ling organized a group of women from Beijing who went to Baoding when soldiers wounded in nearby fighting filled all the local hospitals. ${ }^{127}$ Xie Bingying claimed that she could have brought more to the front had she not had to leave in haste. As Xie recalled, "My program was no sooner announced than many nurses and female students got in touch with me-and thus the Hunan Women's War Zone Service Corps was established in four days flat." 128 As educated urban women and published authors, both Ding Ling and Xie Bingying could draw on a wide network of like-minded women who wanted the adventure of serving at the battlefront. Xie described it in this way:

We received no official support for this project because some people said women should work only behind the lines, at home. We, on the contrary, seized the opportunity to rush to the front lines. In fact, everywhere in China women were beginning to mobilize. ${ }^{129}$

Working at their nation's front lines, women mobilized themselves to heal and soldiers to kill.

\section{CONCLUSION}

All available information confirms that, despite the brutality of the fighting, disease constituted the Chinese soldiers' greatest killer during the War of Resistance. This yields a heartbreaking picture of a conflict that China did not choose, that came too soon, and that thoroughly exacerbated all the extant problems in the country's healthcare system. The Nationalist government's failure to prioritize and sufficiently fund civilian health systems before the war ensured that most new soldier recruits hailed from villages and cities with minimal health services, while the chaos and disruption of the war itself often left them malnourished and overworked. Soldiers frequently began their military experience already in a poor physical state, and the deplorable conditions of recruitment camps and medical facilities both behind and at the front lines, coupled with the stressors of military life, ensured a low survival rate for the average NRA soldier. Soldiers suffered unduly from diseases, untreated wounds, poor sanitation, lack of clean drinking water, and insufficient food and clothing to such a degree that they themselves constituted an abused social group, asked to sacrifice their lives for the very state that failed to protect their bodies. Being a poor man of military age during the war considerably decreased one's life expectancy.

A handful of well-trained and dedicated medical professionals aligned their work against two formidable enemies: soldiers of the Imperial Japanese Army, and 
disease microbes. Nonetheless, their due diligence could not solve the underlying problem of deep ideological divides that made sympathy for soldiers appear morally and politically suspect to certain Nationalist authorities. The two most competent leaders in military medicine during the war came under suspicion of being Communist, and only one managed to avoid damage to her career. Most egregiously, Nationalist Party rightists got in the way of soldiers' lifesaving health services on the battlefields where they spilled their blood on behalf of a state that prioritized politics over human lives. While no one can prove that the Nationalist Party would have been more open to compromise had the war not pushed it to near extinction, there is ample evidence that the war escalated tensions both within the Nationalist Party and between it and the Communist Party. Over and over again, people who possessed a spirit of service, who willingly underwent personal privations in order to help others, who treated the poor as worthy human beings, were suspected of being Communists and persecuted. Those who made it to the top of the Nationalist Party power structure, with the dogmatic ideologue Chiang Kai-shek in charge, had no means of understanding such a commitment, feared its ardor, and treated its proponents like political enemies. Lim Kho Seng and Zhou Meiyu proved unstoppable, as did their institutions, but the rift between the Communists and the Nationalists continued to grow until it eventually tore the country apart. In a broader sense, the War of Resistance pushed both the Nationalist and Communist parties to the edge and exacerbated their mistrust of one another despite the renewed United Front agreement. It also gave members of each party a distinct experience of the war, in two very different regions of the country, that could be told as an exclusive narrative, and each has been told in this way for decades. ${ }^{130}$

One way to interpret the competing visions of military medicine is as two distinct "emotional communities." Historian of emotions Barbara Rosenwein created this concept to describe groups of people who may or may not share social communities such as neighborhoods, temples, and native place associations, but who do share normative values about the expression (or suppression) of certain emotions. Multiple emotional communities exist in any time and place, but people can move between different emotional communities only if they overlap significantly. ${ }^{131}$ Interpreting rightist Nationalists' disdain for Communists and medical workers' insistence that Communists be given equal treatment as reflections of distinctive emotional communities suggests that China's civil war between the two parties had an important emotional component. The War of Resistance sponsored the creation of two ultimately incommensurable emotional communities. In the end, the fissure that tore the country in two appeared along a political and emotional fault line and drove members of the two communities to two distinct territories: mainland China and island Taiwan. Thinking in terms of emotional communities further shows just how deeply "nested" the War of Resistance and Civil War were 
within one another, since the process of the two communities moving apart began in the former but crystalized in the latter. ${ }^{132}$ Viewed through the lens of the history of emotions, the gendered analysis of military medicine helps to explain why the Nationalists won the war against Japan but eventually lost to the Communists in a civil war during which entire battalions switched sides.

Necropolitics and the logic of war as organized injury help to explain the apparent contradiction in the fact that nurses' emotional labor to save the lives of soldiers was simultaneously a labor to endanger their lives yet again. While female medical workers challenged patriarchal gender norms that would have them stay indoors, they also extended the power of the patriarchal state by embodying its control of citizens' and soldiers' bodies. Because they worked during a war, female nurses were trained to employ their gender to shame men into performing their obligatory masculine role by returning to the terrifying battlefield to risk their lives once more in defense of the nation. Battlefield conditions and Japanese soldiers' ferocity suffice to explain why a healed soldier would resist returning to the front, but in the hands of Zhou Meiyu, China's military medicine system accounted for this reticence and mobilized women to police the men's gender performance through conformance to their own prescribed gender roles as gentle caretakers. Military nurses worked within a structure tightly defined by gender, but also exercised their own agency to bring death and destruction to the enemy. Female nurses proved so useful to the military that the Army Medical Administration stopped accepting male nursing students in 1947. Though the exigencies of the Civil War soon forced them to accept men who already had nursing training, the message was loud and clear. ${ }^{133}$ Women had proven themselves of utmost utility to the masculinist state. The "Sick Woman of East Asia" had become her country's best healer. 